\title{
Soybean-based Surfactants and Their Applications
}

\author{
Qingyi $\mathrm{Xu}^{1}$, Mitsutoshi Nakajima ${ }^{2}$, Zengshe $\mathrm{Liu}^{3}$ and Takeo Shiina ${ }^{1}$ \\ ${ }^{1}$ National Food Research Institute, \\ ${ }^{2}$ University of Tsukuba, \\ ${ }^{3} N C A U R / A R S / U S D A$, \\ 1,2Japan \\ ${ }^{3}$ U.S.A
}

\section{Introduction}

The soybean is a legume that contains no cholesterol and is low in saturated fat. Soybeans have been consumed as a major source of protein by people in Asia for centuries, while their consumption in the West only spans several decades. The soybean is the only vegetable food that contains all eight essential amino acids. It is also a good source of fibre, iron, calcium, zinc, and vitamins. In 2009, the world soybean production was 210.9 million metric tons, about $53 \%$ of the world oilseed production [American Soybean Association, 2010]. Soybeans are made up of about $40 \%$ protein and $20 \%$ oil and are therefore considered to be a major source of proteins and oils. They are also an important source of three natural surfactants: soy lecithin, soy protein, and soy saponin. However, the use of saponin has some limitations [Oleszek \& Hamed, 2010]. In this chapter, we are focusing on soy lecithin and soy protein.

A surfactant is a surface-active substance. The molecular structure of a surfactant is characterised by the presence of hydrophilic heads and lipophilic tails. This structural property enables surfactant molecules to adsorb at surfaces or interfaces. Surfactants are generally classified according to the type and charge of the hydrophilic groups, namely, anionic, cationic, nonionic, and amphoteric surfactants. Surfactants are involved in many aspects of our lives, including detergents, cosmetics, foods, and drinks. Not only natural surfactants but also a wide range of synthetic surfactants are used in various applications. The world surfactant market was valued at about $\$ 14.3$ billion [Karsa \& Houston, 2006] with a market volume of about 18 million tons [Cirelli et al., 2008] in 2003, and it reached \$23 billion in 2007 [Acmite Market Intelligence, 2008]. However, the market has recently been experiencing stricter regulations and has been hit by the current financial crisis. Surfactants can be produced both from oleochemical and petrochemical feedstocks. The use of natural renewable materials (e.g., seed oils and animal fats) to produce surfactants coupled with the development of new production methods may provide a solution to these challenges. Furthermore, it has been demonstrated by life cycle analysis that the use of renewable resources for surfactant production is more cost-effective and eco-friendly than petrochemical resources. The substitution of the use of seed oils for surfactant production would lead to a significant reduction in surfactant-associated $\mathrm{CO}_{2}$ emissions [Patel, 2004]. Therefore, it is expected that the production of seed oil-based surfactants will continuously increase and that surfactants with novel and improved properties will be developed. 


\section{Soy lecithin}

\subsection{Composition of soy lecithin}

The term "lecithin" is used to refer to a mixture of phospholipids, a natural constituent of animals and plants. Egg yolk is the primary animal source of lecithin, but it is too expensive for industrial applications. Lecithin is now predominantly manufactured from plant seeds, mainly from soybean oilseeds due to their abundant availability and low cost. Crude soybean oil contains 1-3\% phospholipids. These phospholipids are extracted as a by-product at a pretreatment stage during oil refinement. The composition of lecithin varies according to the method of extraction and purification. Commercial soy lecithin contains about $65-75 \%$ phospholipids (PLs), 34\% triglycerides, and smaller amounts of carbohydrates, pigments, sterols, and sterol glycosides [Dickinson, 1993]. The most common PLs in lecithin are phosphatidylcholine (PC), phosphatidylethanolamine (PE), and phosphatidylinositol (PI). The PC content ranges from 29-46\%; PE, from 21-34\%; and PI, from 13-21\% [Garti, 2002]. Because of its structural and compositional properties, soy lecithin is widely used as an emulsifier, antioxidant, stabiliser, lubricant, wetting agent, and nutritional supplement [Li, 2006]. In this chapter, we are focusing on the structural and functional properties of soy lecithin related to its surface activity and use as a surfactant.

\subsection{Structural and functional properties of soy lecithin}

PLs are diglycerides with a phosphate group attached to the third carbon atom of the glycerol molecule. The structures of PLs are shown in Fig. 1. The head group can be choline, ethanolamine, or inositol to form PC, PE and PI. The fatty acid composition of PLs may differ in chain length and saturation due to their response to environmental conditions (Dornbos et al., 1989). PLs are amphipathic molecules with hydrophilic polar heads and hydrophobic nonpolar fatty acid tails. As amphipathic molecules, they tend to adsorb to surfaces or interfaces with the nonpolar fatty acid tails facing the surface or oil phase and the polar heads facing the water phase, resulting in a decrease in the surface or interfacial tension. The PL molecules at the surface of bubbles, oil droplets or water droplets act as barriers to stabilise them.

The molecules of PC and PE contain positively charged choline (for PC) and ethanolamine (for PE) groups and negatively charged phosphate and carbonyl groups. PC and PE are zwitterionic-type surfactants, and they are electrically neutral at neutral $\mathrm{pH}$. PI has a net negative charge at neutral $\mathrm{pH}$ and is an anionic-type surfactant (Gierula et al., 1999; Wang \& Wang, 2008). PC tends to facilitate the formation of oil-in-water $(\mathrm{O} / \mathrm{W})$ emulsions, while PE and, to a lesser extent, PI tend to facilitate the formation of water-in-oil (W/O) emulsions [McClements, 2005]. Because commercial lecithins are mixtures of phospholipids and other substances, their surface activities are a combined result of all surface active components. Lecithin is universally accepted for medicinal and food use because its constituent phospholipids can be metabolised in vivo [Dickinson, 1993]. Although lecithin is not particularly suitable for stabilising either $\mathrm{O} / \mathrm{W}$ or $\mathrm{W} / \mathrm{O}$ emulsions, it can be used to prepare both $\mathrm{O} / \mathrm{W}$ and $\mathrm{W} / \mathrm{O}$ emulsions when exposed to an appropriate $\mathrm{pH}$, salt concentration, temperature, and oil/water ratio [McClements, 2005; Krawczyk, 1996]. PC and PE do not contribute significantly to the net charge on the emulsion droplets at physiological $\mathrm{pH}$, whereas PI and other anionic components in lecithin contribute to the negative charge of the emulsion and thus to emulsion stability [Dickinson, 1993; Wang \& Wang, 2008]. 
<smiles>[R]COC(=O)C(COC([R])=O)COP(=O)([O-])OCC[14CH3]</smiles>

3-sn-Phosphatidylchloline (PC)

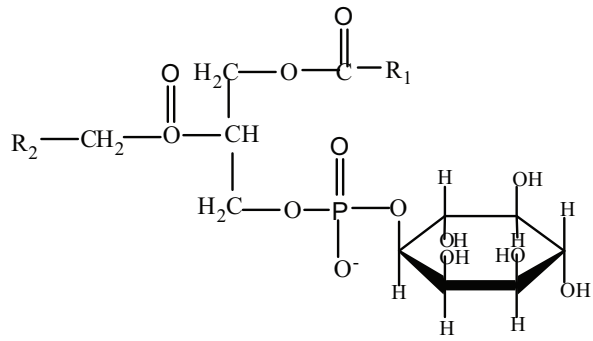

3-sn-Phosphatidyl inositol (PI)<smiles>[R]COC(COC([R])=O)COP(=O)([O-])OC[NH3+]</smiles>

3-sn-Phosphatidyl ethanolamine (PE)

$\mathrm{R}_{1}$ and $\mathrm{R}_{2}=$ Different hydrocarbon chains

Fig. 1. Structures of phospholipids.

When dispersed in excess water above the chain melting temperature (CMT), PC and PI form a lamellar liquid crystal, whereas PE forms either a lamellar or hexagonal structure depending on the temperature, water content, and the composition of the hydrocarbon chains [Rydhag \& Wilton 1981]. In the case of mixed PLs, only the lamellar packing is formed. Rydhag \& Wilton (1981) reported that soy lecithin forms a lamellar liquid crystalline phase to stabilise $\mathrm{O} / \mathrm{W}$ emulsions. A minimum thickness of the interfacial film of $\sim 80 \AA$, corresponding to two double lipid layers, is required for the stabilisation the emulsions. They found that the amount of charged lipids has a strong effect on the ability of the lamellar liquid crystalline phase to swell with water. The charged components of lecithin contribute to the stability of the emulsions in terms of the fast adsorption to the oil/water interface, the formation of the swollen lamellar structures, and the electrostatic repulsion. Comas et al. [2006] observed that changing the $\mathrm{pH}$ from 6.2 to 2.0 resulted in an increase in the oil droplet diameter due to either the reduction in the surface activity of soy lecithin or the formation of a less resistive interfacial film. As a result, the droplets are more susceptible to coalescence in an acidic environment.

Lecithin forms reverse micelles in many organic solvents. The structure of reverse micelles depends on the concentration, temperature and water content. It has been demonstrated that giant cylindrical reverse micelles are formed when adding small amounts of water. A viscous gel referred to as organogel can then be formed as the water content increases. A further increase in the water content to a suitable content range results in the formation of stable $\mathrm{W} / \mathrm{O}$ emulsions, which are stabilised by the presence of a lamellar phase and the viscous oil phase [Palazzo et al., 2003; Angelico et al., 2004; Stefan et al., 2003]. 
Conventional methods for preparing emulsions or bubble dispersions include mechanical homogenisation, sonication, and high-pressure homogenisation, which usually results in the formation of droplets or bubbles with wide size distributions. The demand for preparing droplets or bubbles with uniform sizes is increasing to improve the functionality and stability of products. Membrane emulsification [Nakashima et al., 1991] and microchannel emulsification [Kawakatsu et al., 1997] are two well-studied methods for preparing monodisperse emulsions. In these cases, the interaction between the charged groups of lecithin and the surface of membranes or microchannels may greatly influence the emulsification performance. The coalescence of the formed droplets and the continuous outflow of the oil phase through the microchannel were observed when using lecithin to produce an $\mathrm{O} / \mathrm{W}$ emulsion with a silicon microchannel emulsification system. This was considered to be due to the attraction interaction between the positively charged groups of PC and PE and the negatively charged microchannel surface, causing the wetting of the surface of the microchannel by the oil phase. As a result, the surface of the microchannel lost its hydrophilicity and monodisperse droplets cannot be prepared. Increasing the experimental temperatures up to $70^{\circ} \mathrm{C}$ did not improve the droplet production [Tong et al., 2002]. The most commonly used membrane for membrane emulsification is the Shirasu porous glass (SPG) membrane. The SPG membrane is suitable for the preparation of $\mathrm{O} / \mathrm{W}$ emulsions because of the presence of negatively charged silanol groups on the membrane surface [Vladisavljević et al., 2005]. Surh et al. [2008] found that soy lecithin, despite its net negative charge, tends to foul SPG membranes by blocking the membrane pores due to the interaction between positive groups on the lecithin molecules and anionic silanol groups on the membrane surface.

\subsection{Use of soy lecithin in combination with other additives}

Although soy lecithins are important natural-sourced surfactants that have been used in various industries, they do not have a wide range of emulsifying properties [Dickinson, 1993]. Furthermore, emulsion products usually contain different components. The functional property of lecithin may be affected by the presence of other ingredients. PLcoated microbubbles have shown potential as ultrasound contrast agents and drug delivery systems. By using PL (L- $\alpha$-phosphatidylcholine) in combination with an emulsifier (polyethylene glycol 40 stearate-40), stable microbubbles with diameters of less than $10 \mu \mathrm{m}$ and narrow size distributions can be prepared by coaxial electrohydrodynamic atomisation (CEHDA) [Farook et al., 2009]. Extensive investigations have been performed on the use of soy lecithin in combination with proteins. Compared with other surfactants, the lecithinprotein interaction appears to be more complicated because of the complex liquid crystalline phases formed in water [Dickinson, 1997]. The interactions between protein and lecithin may change the structure of protein, leading to the formation of protein-lecithin complexes. As a result, the emulsifying properties and the electrostatic and steric repulsions may be changed. This may have synergistic effects on emulsion properties in some cases and antagonistic effects in others. The heat stability of caseinate-stabilised emulsions was found to be improved by adding lecithin before homogenisation [Cruijsen, 1996]. McCrae [1999] demonstrated that lecithin does not exercise its effect on heat stability by interacting with free protein in solution but that it does with adsorbed proteins. However, the addition of lecithin destabilised whey protein hydrolysate-stabilised O/W emulsions, supposedly due to the displacement of protein molecules by the competitive adsorption of lecithin at the 
interface [Agboobla et al., 1998]. The displacement of protein by lecithin was also observed in $\mathrm{O} / \mathrm{W}$ emulsions stabilised by whey protein concentrate (WPC). However, no displacement of adsorbed protein by lecithin was found in the emulsions stabilised by $\beta$ lactoglobulin. The greater susceptibility of WPC to displacement from the surface of droplets by lecithin was explained as resulting from the denaturation of the protein [Dickinson \& Yamamoto, 1996]. PLs are regarded to be less effective at competitively displacing milk proteins from the oil-water interface [Dickinson, 1997].

The presence of fat crystals can either stabilise or destabilise emulsion droplets, depending on which phase they are in. When present in the continuous phase, they may adsorb onto the droplet surfaces to stabilise the emulsion by providing a physical barrier. When present in the oil phase, they may destabilise $\mathrm{O} / \mathrm{W}$ emulsions because the fat crystals stick out into the water phase and/or pierce the interfacial film [Boode et al., 1991; Rousseau, 2000]. Lecithin was found to affect the crystallisation of oil and thus have an impact on the stability of O/W emulsions [Miura et al., 2006]. The competitive adsorption of lecithin to displace proteins adsorbed at the oil/water interface may cause a change in the interactions between the proteins and fat crystals and thus affect the mechanical strength of the interfacial film [Ogden \& Rosenthal, 1997], while the competitive adsorption of lecithin to displace proteins adsorbed at the surface of fat crystals may facilitate the coalescence of fat globules and thus destabilise the emulsions [Melsen \& Walstra, 1989]. The adsorption of lecithin may also change the polarity of fat crystals [Johansson \& Bergenståhl, 1992; Rousseau, 2000].

Usually, low-molecular-weight surfactants are effective at generating emulsions with smaller droplets because of their fast adsorption to the newly created interfaces, but they may not be effective at providing long-term stability to the emulsions. The effect of the addition of sucrose and a non-gelling polymer (hydroxy ethy1 cellulose) on the stability of lecithin-stabilised O/W emulsions was investigated by Castelain et al. [1990]. The sucroseadded emulsions showed improved stability towards coalescence, flocculation, and creaming, while the polymer-added emulsions exhibited improved stability towards coalescence but reduced stability against flocculation and creaming. A recent study showed that by using a two-step procedure, it is possible to prepare lecithin-stabilised $\mathrm{O} / \mathrm{W}$ emulsions containing small cationic droplets coated with a two-layer membrane. Through conferring a polymeric outer layer to the droplets, the stability against thermal processing, freeze-thaw cycling, and high calcium ion contents as well as iron-catalysed lipid oxidation were enhanced [Ogawa et al., 2003].

\subsection{Modification of soy lecithin}

Commercial soy lecithin contains about $34 \%$ triglycerides. De-oiling is thus conducted to obtain lecithin with a high PL content. Acetone de-oiling is a conventional method for removing triglycerides due to the fact that triglycerides are soluble in acetone while PLs are insoluble [Wu \& Wang, 2003; Vikbjerg et al., 2006]. Up to about 90\% of PL-enriched lecithin can be obtained using this method. Another method for de-oiling employs a silica column with hexane solution. Separation is realised by the adsorption of neutral lipids while PLs pass through the column [Schneider, 1989]. However, de-oiling results in an increase in the PL content without changing the ratios of the PL types [Joshi et al., 2006].

Because technical soy lecithin is a complex mixture of different PLs and other substances, its properties and application depend on the composition. For example, weakly hydrophilic lecithin can be used to prepare W/O emulsions, while more hydrophilic lecithin can be used 
to prepare $\mathrm{O} / \mathrm{W}$ emulsions. Therefore, separation or increasing the content of individual components is of practical importance. Solvent extraction is one of the most widely used methods for the fractionation of crude lecithin due to the different solubilities of PL fractions. The efficiency of solvent extraction may vary according to the type and concentration of the solvent used and the time and temperature of the extraction. For example, ethanol and/or aqueous ethanol are used to fractionate PC and PI because PC has a higher solubility in ethanol than PI [Wu \& Wang, 2003; 2004]. Both the PC- and PI-enriched fractions show a much lower critical micelle concentration (CMC) than commercial lecithin. The PI-enriched fraction has a higher surface activity than the PC-enriched fraction in terms of CMC and surface tension. This is probably due to the fact that PI contains more saturated and less unsaturated fatty acids than PC [Wu \& Wang, 2003]. For W/O emulsion, it was agreed that the PI-enriched fraction is a better emulsifier than the PC-enriched fraction. For O/W emulsion, however, different conclusions were drawn [Wu \& Wang, 2003; Hui, 1996]. Chromatographic separation is another way to prepare pure fractions of PLs. The drawback of this method is that a large volume of solvent is used, and thus it is cost ineffective [Teberikler et al., 2001].

With increasing health and environmental concerns regarding the use of organic solvents, the development of new technologies to fractionate lecithin without using solvents has been facilitated. Supercritical carbon dioxide (SC-CO2) is an excellent solvent for nonpolar lipids such as triglycerides and fatty acids while PLs have limited solubility in it [Teberikler, 2001]. It has been used as an alternative to organic solvents [Nasir et al., 2007]. SC- $\mathrm{CO}_{2}$ has shown to be very effective in removing oils from a variety of seed matrices. After de-oiling, the PLs can be extracted with SC-CO 2 /ethanol [Montanari et al., 1999]. However, cost is a major concern as the processes are usually performed under high pressures and high temperatures. Manjula \& Subramanian [2008] investigated the de-oiling of lecithin using a nonporous polymeric membrane and hexane as the solvent. Their results demonstrated that the membrane is a promising alternative for the de-oiling of lecithin, especially in terms of cost effectiveness.

To improve the solubility and to modify the functionality of lecithin, soy lecithin can be chemically hydrolyzed by strong acids or alkili and enzymatically hydrolyzed. Because of the difficulty of producing lecithin with controlled structures using chemical methods and properties, the enzymatic method is preferred. Two major groups of enzymes are used: phospholipases and lipases. Phospholipase A2 is the most commonly-used phospholipase, which specifically hydrolyses the sn-2 fatty acyl group of PLs to form lyso-PLs. By using different enzymes or a combination of enzymes under different conditions, it is possible to produce hydrolysed lecithins with a wide range of properties [Nieuwenhuyzen \& Tomas, 2008]. Partially hydrolysed lecithins are more hydrophilic and show enhanced O/W emulsifying properties [Nieuwenhuyzen, 1976; List, 1989]. It has been reported that the presence of divalent ions such as calcium and magnesium ions may cause a destabilisation of the emulsions. An increased resistance to these ions was observed in the emulsions prepared with hydrolysed lecithins [Nieuwenhuyzen, 1976]. Furthermore, tailored properties can be obtained by specific exchange of the acyl group in the sn- 2 position of a PL, which is characterized by reacting the PL with a free fatty acid in the presence of phospholipase A2 [Pedersen, 2001]. PC structures synthesised by enzymatically exchanging the long chain fatty acids with medium chain fatty acids are more hydrophilic and are thus better emulsifiers for O/W emulsions [Vikbjerg et al., 2006].

Lecithin can also be modified by hydrogenation, which involves the reaction of PLs with hydrogen gas in the presence of a catalyst to add hydrogen to the unsaturated fatty acids [Lantz, 1989]. Hydrogenated lecithins show greater oxidative stabilities and higher melting 
points but lower solubilities in oils and fats [Nieuwenhuyzen, 2010]. They are used in chocolate formulations and emulsions for intravenous injections [List, 1989]. Another way to modify lecithin is by hydroxylation, which is carried out by the reaction of lecithin with hydrogen peroxide and lactic acid or a peracid to form hydroxyl groups in the unsaturated fatty acid chains. The amino group of the PE can also be modified [Nieuwenhuyzen, 1981; List, 1989]. The O/W emulsifying properties of hydroxylated lecithins are significantly improved as a result of the enhanced water dispersibility [Nieuwenhuyzen, 1981]. Hydroxylated lecithin has GRAS (generally recognised as safe) status (21 CFR 172.814) in the USA, but it is not listed in the EU Food Additive Directive [Nieuwenhuyzen, 1998]. Acetylation of the head group of the phospholipids, primarily the amino group of PE, is a well-used method for modifying the structure and property of PLs [Nasir et al., 2007]. Soy lecithin can be acetylated by chemical methods using acylating agents such as acetic anhydride. However, chemical acetylation suffers several drawbacks, including incomplete and non-selective acetylation and the formation of decomposition products that result in dark-coloured reaction products. Enzymatic acetylation is, therefore, employed to selectively acetylate the amino group of PE [Marellapudi et al., 2002]. Acetylated lecithins exhibited improved fluidity, solubility, and resistance to heat and darkening. The enhanced emulsifying property makes them effective emulsifiers for $\mathrm{O} / \mathrm{W}$ emulsions [Dashiell \& William, 1984; Marellapudi et al., 2002; Nasir et al., 2007].

\subsection{Applications of soy lecithins}

Soy lecithin is highly valued because of its natural origin, abundant supply and multiple functionalities. Its safety has been confirmed by the World Health Organization [WHO, 1974]. It is one of the few emulsifiers that have been awarded GRAS status by the US Food and Drug Administration FDA. Standard lecithin, fractions, and acetylated lecithin are listed in 21CFR184.1400; enzyme-modified lecithin in 21CFR184.1063; and hydroxylated lecithin in 21CFR172.814 [Nieuwenhuyzen, 2010]. Native soy lecithins and modified soy lecithins are important emulsifiers and stabilisers in the production of emulsion, foam/bubble products and others, and thus have found applications in various industries where these products are used. Currently, the most used lecithins in the food industry are soy lecithins, with a use level of about $0.1 \%$ to $2 \%$. They are often used in combination with synthetic surfactants to reduce the amount of the synthetic surfactants [Rust \& Wildes, 2008]. In the food industry, the deoiled lecithin is preferred over purified PLs due to cost considerations [Vikbjerg et al., 2006]. Lecithins are added to food products to improve their quality and shelf life. For example, lecithin provides significant reduction in the viscosity of chocolates and coatings [Weyland \& Hartel, 2008]. In margarine, lecithin plays an important role in anti-spattering by stabilising the water droplets. The addition of lecithin enhances the volume and freshness of baked goods [Nieuwenhuyzen \& Tomas, 2008]. Lecithin is also used as a food supplement to improve cardiovascular health as well as to enhance memory and physical endurance [Nieuwenhuyzen \& Tomas, 2008].

As amphiphilic molecules, PLs may form micelles, liposomes, bilayer sheets, lamellar structures, or organogel in aqueous solutions according to the concentration, hydration, and temperature. These self-assembling systems are potential delivery systems for active ingredients and drugs. Purified fractions and modified PLs are often utilised in these areas. Extensive research has been conducted on the use of these self-assembling systems to deliver drugs and genes and to treat diseases and cancers, which is beyond the scope of this chapter. In the food industry, liposomal nanoencapsules have been used as controlled 
delivery systems for products such as nutraceuticals, enzymes, vitamins, flavours, pesticides, and antimicrobials. The use of these nanoencapsules shortens the processing time of cheese products, fortifies the nutritional quality of dairy products, prevents the degradation of food components, and improves the safety of food products [Taylor et al., 2005].

\section{Soy protein}

\subsection{Soy proteins and their structural and functional properties}

The protein content of soybean seeds is about $40 \%$. It is known that the main soy proteins are globulins that can be classified into 2S, 7S, 11S, and $15 \mathrm{~S}$ fractions according to their sedimentation rates during centrifugation. The 7S ( $\beta$-conglycinin) and $11 S$ (glycinin) fractions are the major components of soy proteins, accounting for about $40 \%$ and $30 \%$ of the total seed proteins, respectively. Their contents vary with soybean variety and environment [Iwabuchi \& Yamauchi, 1987; McSweeney, 2008; Mujoo et al., 2003]. The amount of 7 S and $11 S$ proteins in soy protein products depends on the extraction method and thus affects the functional properties of the soy protein products. The 7S protein is a trimer consisting of $\alpha^{\prime}$, $\alpha$, and $\beta$ subunits with a molecular weight of approximately 200,000. The $11 S$ protein consists of six subunits, each made up of an acidic polypeptide chain linked by disulfide bonding to a specific basic polypeptide chain with molecular masses of approximately 330,000 [Mujoo et al., 2003]. It has been reported that the 7S globulin has a higher functionality (e.g., solubility and emulsification) than the 11S globulin, which is attributed to the relatively stable oligomeric structure of the $11 S$ globulin [Chove, 2007].

Soy proteins are obtained after the extraction of soybean oil. After the hulls and the oil are removed, the remaining defatted flake has a protein content of approximately $50 \%$ [Endres, 2001]. Soy proteins are available in three major forms based on protein content: soy flours, soy protein concentrates and soy protein isolates. Soy flours are the least refined forms of soy protein products containing $50-59 \%$ protein. Soy flours are obtained by grinding defatted soy flakes and may vary in fat content, particle size, and degree of heat treatment. The functionality of soy flours is related to their capacity to bind water and absorb fat. In general, lower heat treatment and smaller particle size means more functionality [Endres, 2001; Lai \& Lin, 2006]. Soy protein concentrates are obtained by aqueous liquid extraction or an acid leaching process and contain $65-72 \%$ protein. Non-proteic constituents (mainly soluble minerals), carbohydrates, low molecular weight nitrogen compounds and antinutritive factors are removed from defatted meal [Moure et al., 2006]. Soy protein concentrates with different properties can be produced by using different extraction methods or solvents. Compared to soy flours, soy protein concentrates have improved flavour characteristics. The major functionalities of soy protein concentrates are emulsification, water and fat absorption, viscosity control, and texture control [Endres, 2001]. Soy protein isolates are the most refined forms of soy proteins and contain $90 \%$ protein. They are obtained by aqueous or mild alkali extraction followed by isoelectric precipitation. Sugars and other water-soluble materials as well as cotyledon fibres are removed [Park et al., 2002; Endres, 2001]. Membrane technology has been reported to be effective in the preparation of soy protein isolates. Compared to the protein products prepared by isoelectric precipitation, the obtained protein products showed improved functional properties, especially the emulsifying properties [Moure et al., 2006]. Soy protein isolates provide diverse functionalities that enable them to modify the physical properties of 
food products. Neutralised isolates are usually highly soluble. They possess both emulsifying and emulsion-stabilising properties. They are excellent binders of fat and water, and they are good adhesive agents. They vary mainly in their dispersibility, gelling, and viscosity characteristics [Endres, 2001]. The characteristics of soy proteins depend on the method of preparation and on processing conditions such as $\mathrm{pH}$, ionic strength, and temperature.

Soy proteins are important natural polymeric emulsifiers that have been used in various applications. During emulsification, soy proteins adsorb to the newly formed interfaces to facilitate the formation of emulsions. Proteins having a more flexible structure can be more efficient in orienting their hydrophobic segments towards the oil phase and the hydrophilic segments towards the aqueous phase, and thus have a higher emulsifying activity. Consequently, the emulsifying properties of soy proteins are governed by their dispersibilities, surface hydrophobilities and conformational mobilities. The extent of unfolding depends on the available surface area, the amount of time spent in contact with the interface, and the macromolecular structure prior to adsorption [Dickinson, 1993; Molina et al., 2001]. After adsorption at the interface, proteins form a thick interfacial layer to stabilise the emulsion.

The foaming properties of soy proteins have been widely studied [Foegeding et al., 2006; Kinsella, 1976; Vani \& Zayas, 1995; Ortiz \& Wagner, 2002; Chove, 2007]. It has been reported that a high dispersibility of the protein is required for the formation of foam, while the unfolding of the proteins at the interface governs the stability of foam. Hence, the solubility of soy proteins greatly influences the foaming property but not the foam stabilisation property [Foegeding et al., 2006; Liu, 1997; Kinsella, 1976]. Therefore, proteins with high foaming abilities do not necessarily result in high foam stabilisation abilities and vice versa [Vani \& Zayas, 1995]. Foam formation is also affected by the size of the proteins, which is related to the migration and adsorption of the proteins at the interface [Ortiz \& Wagner, 2002].

For a surface-active molecule to be a good surfactant, it must be capable of rapid adsorption at the air-water or oil-water interface to reduce the surface or interfacial tension. In this regard, low molecular weight surfactants (e.g., lecithin) are more effective than high molecular weight surfactants (e.g., proteins). Proteins, however, are more effective in conferring stability on emulsions and foams than low molecular weight surfactants. The stability of protein-stabilised emulsions and foams is determined by the properties of the interfacial adsorbed layer such as the surface coverage, the layer thickness, and the surface charge density, which are affected in turn by the aqueous solution conditions, for example, $\mathrm{pH}$, ionic strength and the presence of other ingredients [Dickinson, 2003].

\subsection{Use of soy proteins in combination with other additives}

Most soy protein-containing products are multi-component systems. In some cases, proteins alone cannot provide desirable functionality so other ingredients are added to achieve the desired functionality. The functional properties of proteins can be improved by using proteins in combination with other additives. A synergistic effect between soy protein and casein was reported in which the loops of caseins protrude into the aqueous phase to provide steric stability while the globular soy protein may contribute viscoelasticity. The composition and structure of the interfacial film may be affected by the ratio of soy protein and casein caused by the competitive adsorption between the two proteins [Damodaran, 2005]. The competitive adsorption between the proteins is much more complicated than that 
between a protein and a low molecular weight surfactant due to the slower adsorption and greater energy needed for desorption [Murry, 2007].

Special focus has been given to improving the functionality of soy proteins by constructing protein-PL or protein-polysaccharide complexes [Dickinson, 1993]. When proteins co-exist with low molecular weight surfactants in a dispersed system (e.g., emulsion and foam), competitive adsorption between proteins and low molecular weight surfactants occurs, resulting in a reduction in the amount of adsorbed protein. Above a critical surfactant concentration, complete displacement of protein molecules may take place, depending on the nature of the surfactants and the oil phase (Dickinson \& Tanai, 1992). As a result, the composition, structure, and property of the interface layer may be changed, which in turn affect the property and stability of the dispersed system.

The combination of lecithin and protein may have a synergistic effect or an antagonistic effect on the stability of dispersed systems due to the displacement of protein from the interface by lecithin. Interactions between proteins and PLs may cause changes in surface activity, protein structure, molecular flexibility, and net charge and may lead to the incorporation of protein into surfactant micelles or vesicles [Nieuwenhuyzen \& Szuhaj, 1998]. Scuriatti et al. [2003] described that the emulsions prepared with the addition of PC exhibited improved stabilities against creaming and mechanical stirring compared to the emulsions prepared with native soy protein isolates (NSI) alone. The addition of sodium chloride was found to destabilise the NSIPC-stabilized emulsions. A lesser degree of destabilisation was observed in the emulsions prepared with denatured soy protein isolates (DSI) and PC, suggesting stronger interactions between the denatured protein and PC. A recent study by Comas et al. [2006] showed that the presence of soy lecithin enhanced the emulsion stability of a DSI system at all $\mathrm{pH}$ values studied (2.0, 5.5, and 6.2), while it enhanced NSI stability only at $\mathrm{pH} 2.0$. Lecithin is likely to contribute to surface charges rather than to to an increase in the surface activity. Heat treatment of a soy protein isolate-lecithin mixture reportedly led to an enhancement in the emulsification activity, mainly due to the denaturation of the 11S globulin [Hirotsuka et al., 1984]. Differences between NSI-lecithin and DSI-lecithin systems are thus thought to be caused by the differences in protein structure and charge property.

Proteins and polysaccharides are two major biopolymers that contribute greatly to the stability and rheology of food colloids. In dispersed systems, proteins can act as emulsifying/foaming agents and stabilisers by adsorbing at the air-water or oil-water interface and forming a protective interfacial layer, while polysaccharides mainly act as stabilizers through their thickening and gelling behaviour [Dickinson \& Galazka, 1991]. A better understanding of soy protein-polysaccharide interactions is critical to the prediction and the control of the stability of foods. Therefore, many studies have been conducted on the interactions between protein and polysaccharide and the effect of proteinpolysaccharide complexes on the formation and stabilisation of emulsion systems. Interactions between proteins and polysaccharides may lead to changes in surface activities and thicknesses of the interfacial layers and thus have an impact on the stability of emulsions [Dickinson, 1993].

Pectin is an acidic polysaccharide mainly extracted from apples and citrus fruits. It is one of the most commonly used polysaccharides in acidic environments and has been used as a gelling agent, thickening agent, and stabiliser in food. Soy soluble polysaccharide (SSPS) is extracted from soybean cotyledons and often used in acidic emulsion-based beverages. A study performed by Roudsari et al. [2006] revealed that SSPS exhibited a different 
stabilization behavior from that of high methoxyl pectin (HMP) in the emulsions prepared with soy protein isolates.. At a neutral $\mathrm{pH}$ and above a critical stabiliser concentration $(0.05 \%)$, HMP caused flocculation of the emulsion droplets via a depletion mechanism while no creaming or flocculation was observed in the emulsions prepared with SSPS. At an acidic $\mathrm{pH}(<4.0)$ the addition of pectin caused extensive droplet aggregation, while no aggregation was observed with the addition of SSPS. The different stabilisation behaviours between the two polysaccharides can be attributed to their differences in charges, neutral sugar side chains, and molecular weights.

By comparing the formation and stability of emulsions prepared with $\beta$-lactoglobulin, a $\beta$ lactoglobulin-dextran mixture and a dry-heated $\beta$-lactoglobulin-dextran composite, Dickinson \& Galazka [1991] concluded that dry-heat treatment enhances the functionality of protein-polysaccharide hybrids. Dry-heat treatment yields a $\beta$-lactoglobulin-dextran complex containing a covalent Maillard-type linkage between the two biopolymers and produces emulsions with excellent stability with respect to creaming, coalescence, and serum separation. In contrast, emulsions prepared with an unheated protein-polysaccharide mixture showed poorer stability than those prepared with protein alone due to the depletion flocculation caused by the presence of unadsorbed polysaccharides. Diftis \& Kiosseoglou [2004] demonstrated that stable O/W emulsions can be prepared by a dryheated SPI-dextran composite. Two factors appear to contribute to the stability of the emulsions. One is that the SPI-dextran conjugate forms a thick interfacial membrane providing steric stabilisation to the emulsions, and the other factor is that the SPI-dextran conjugate changes the effective density of the oil droplets and therefore slows down the creaming of the emulsions [Diftis \& Kiosseoglou, 2004].

As mentioned above, the presence of low-molecular-weight surfactants may cause the displacement of proteins from the interface. It has been proven in a corn oil-water emulsion system that dry-heated SPI-dextran mixtures have improved abilities against competitive adsorption. The presence of low-molecular-weight surfactants (Tween 40 ) in the emulsions stabilised by a dry-heated SPI-dextran mixture led to competitive adsorption between the protein and low-molecule surfactants, resulting in a decrease in the amount of soy protein adsorbed at oil droplet surfaces. However, complete displacement did not occur, and a significant amount of protein-dextran conjugate still remained at the interface, conferring stability to the emulsion even at a surfactant-protein weight ratio of as high as 2 . The presence of Tween 40 did not influence the creaming stability of the emulsions. Glycerol monostearate, however, caused the destabilisation of the emulsions [Diftis \& Kiosseoglou, 2004]. The presence of bovine serum albumin (BSA), a well-characterised protein, resulted in the partial displacement of soy protein but had no effect on the creaming stability of the emulsions.

\subsection{Modification of soy proteins}

The functionalities of soy proteins depend strongly on their three-dimensional structures, hydrophobicities, charges, and solubilities. However, the solubility of soy proteins in aqueous solutions significantly decreases as the $\mathrm{pH}$ decreases to about 5.0, which is the typical $\mathrm{pH}$ range for many food emulsions [McEvily \& Zaks, 1991]. Furthermore, the globular structure of soy proteins prevents them from sufficiently unfolding and rearranging at the oil-water interface [Roesch \& Corredig, 2003], preventing soy proteins from being more effective in reducing interfacial tension. Currently, soy proteins are used as the starting materials for the production of surfactants [Rust \& Wildes, 2008]. Various physical (heat or mild alkali 
treatments), chemical (acylation, alkylation, oxidation, phosphorylation, and deamidation, etc.) and enzymatic (transglutaminase, protease, and peptidoglutaminase) methods have been employed to modify the physico-chemical properties and nutritional value of soy proteins [Hamada, 1992, Molina, 2001, Moure, 2006]. Chemical approaches have several drawbacks, such as the lack of specificity and the loss of nutritional value. Hence, enzymatic hydrolysis is the most widely used method for the modification of soy proteins. It has been demonstrated that enzymatic deamidation improved the solubilities, emulsifying activities, emulsion stabilities, and foaming properties of soy protein hydrolysates [Hamada \& Marshall, 1989]. Hydrolysed soy proteins are important ingredients for food products.

When proteins are subjected to high pressures, their secondary, tertiary and quaternary structures may be changed, which may lead to changes in the functional properties of the proteins. Several studies have been performed on the utilisation of high pressure to modify the functional properties of soy proteins [Kajiyama et al., 1995; Molina et al., 2001]. Highpressure treatment at neutral $\mathrm{pH}$ can improve the emulsifying activity of soy proteins but does not improve their emulsifying stabilities and solubilities [Molina et al., 2001].

It is known that ultrasound is an energy- and time-efficient approach. The interest in the application of ultrasound in various industries is increasing. A recent study indicated that the functional properties of soy proteins can be modified by ultrasound treatment in terms of increased solubility, specific surface area, and emulsion activity index [Jambrak, 2009]. The improvement in the emulsifying property is likely to be the result of the partial denaturation of soy proteins during ultrasound treatment, which facilitated the adsorption of the proteins at the oil-water interface.

\subsection{Applications of soy proteins}

Extensive studies have shown that soy protein products are excellent sources of protein and offer multiple health benefits. In October 1999, the US FDA approved a health claim for soy protein, stating that the consumption of at least $25 \mathrm{~g}$ of soy protein per day may reduce the risk of heart disease. Since then, soy protein has received increased attention. Currently, soy proteins have been used as nutritional and functional ingredients in every food category. Aside from their nutritional value, soy proteins affect the appearance, colour, flavour, taste, and texture of food products [Endres, 2001]. The nutritional aspects of soy proteins have been documented in numerous studies, which is beyond the scope of this chapter. Here, we briefly review some of the applications using soy proteins as surfactants.

In baked products, the addition of soy proteins improves the crust colour, grain, texture, and shelf life of products through improving the emulsification of fats and other ingredients. Soy protein concentrates and isolates are often used in the production of dairy products. Soy protein isolates can be used in emulsified products such as coffee whiteners, liquid whipped toppings, and pre-whipped toppings [Endres, 2001]. For coffee whiteners, the primary function of the protein is to assist in the formation and stabilisation of emulsions, especially when added to coffee. Fats with low melting points were found to interact with the protein to form stable emulsions. For whipped toppings, soy protein isolates help in the formation of emulsions and in the incorporation of air during whipping. In most whipped topping formulations, soy protein isolates are used at a lower level than sodium caseinate (or to replace sodium caseinate) because of their higher viscosities and excellent emulsifying properties. These products are popular because of their low cost and convenience in handling and storage [Kolar et al., 1979]. Soy protein hydrolysates have 
found applications in the production of confections, desserts, toppings, and beverages because of their low molecular weight, increased solubility, and good foaming properties. The production of processed meat products has become a major area for the use of soy proteins. Soy proteins act as binders, emulsifiers, and meat flavour enhancers. Recently, the substitution of animal proteins with vegetable proteins has attracted increasingly attention as a result of the increasing public interest in health. Soy proteins have been added to food products as a substitute for animal proteins. In emulsified meat products (e.g., frankfurters, bologna, and sausage), soy protein concentrates and isolates are added to improve the water and fat binding capacities, emulsification, and stability of the products. The products are excellent in taste, appearance, and flavour [Endres, 2001].

\section{Soybean oil-based biosurfactants}

\subsection{Production of soybean oil-based surfactants}

As stated previously, surfactants can be produced from oleochemical or petrochemical sources. The use of petrochemicals as the raw materials for the production of surfactants dates back to the first half of the $20^{\text {th }}$ century and is attributed to the rapid development of the petrochemical industry, which made petrochemical products available [Karsa \& Houston, 2006]. The concerns over the supply, price and environmental impact of petrochemicals greatly stimulate the use of safer, cost-effective, eco-friendly, biodegradable, naturally-based surfactants to replace petrochemical surfactants. The basic oleochemical feedstocks are plant oils and animal fats. The use of beef tallow has been reduced due to bovine spongiform encephalopathy (BSE) concerns. The primary plant oils are coconut, palm, castor, rapeseed, and soybean oils, with the majority being coconut and palm oil [Karsa \& Houston, 2006].

Soybean oil is the world's second largest source of vegetable oil and dominates the world vegetable oil economy. It is currently the second most consumed edible oil in the world because of its nutritional value, availability, low cost, and wide functionality. The consumption of soybean oil in the world in 2009 was 35.7 million metric tons, about $28 \%$ of the world vegetable oil consumption [American Soybean Association, 2010]. The growth in soybean oil production and the decline in dietary oil consumption due to health concerns have accelerated the development of non-food applications of soybean oil. Soybean oil has been used as a raw material to produce various products ranging from lubricants, plasticizers, painting inks, coatings, biofuels and surfactants [Guo et al., 2007].

For surfactant production, soybean oil is used as a fermentation substrate or a raw material. Surfactants can be produced by various microorganisms using soybean oil or oil wastes as the substrates. Different types of biosurfactants (e.g., rhamnolipid, sophorolipid and mannosylerythritol lipid) have been produced [Muthusamy et al., 2008]. Currently, soybean oil is the predominate feedstock used in the manufacture of soybean-based surfactants [Rust \& Wildes, 2008]. Soybean oil is a mixture of triglycerides consisting of low saturated fat $(15 \%)$ and high unsaturated fat (61\% polyunsaturated, $24 \%$ monounsaturated). Efforts to exploit new applications of soybean oil have been made to improve its reactivity through modification. Triglycerides contain two reactive sites: the double bond in the unsaturated fatty acid chain and the carboxylic ester group linking the fatty acid to the glycerol (Fig. 2). The transesterification reaction between the ester group of the triglyceride and an alcohol is an important reaction for biodiesel production. Attentions have been directed to modifying soybean oil by converting its double bonds to more reactive groups. Epoxidation is a commonly used method for this purpose. The double bonds are converted into more reactive 
epoxide or oxirane ring groups by reacting with peracids or peroxides. The benefits of epoxidised soybean oil (ESO) include its low toxicity, low irritancy, and lack of carcinogenic or non-genotoxic effects (BIBRA, 1988; EFSA, 2004). ESO is a promising intermediate for the production of a variety of soybean oil-based products and is commercially available. Different methods have been employed to modify ESO. The ring-opening reaction is the most predominant reaction for ESO modification. The ring-opening hydrolysis of ESO results in the formation of soy-polyols, depending upon the oxirane content and the extent of hydrolysis. Soy polyols have found applications in a variety of fields such as surfactants and coatings [Guo et al., 2007]. Soy polyols prepared by ring opening reactions of ESO with hydrogen active compounds can be ethoxylated to improve their properties. The obtained ethoxylated soybean polyols have higher hydrophilicities and better compatibilities with water. They can be used as surfactants to prepare foams [Lee et al., 2010].

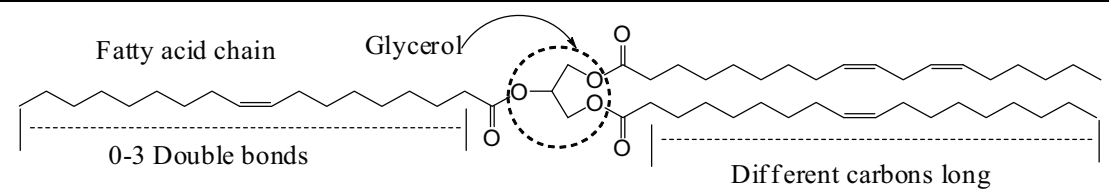

Fig. 2. The structure of soybean oil.

Polymeric surfactants can also be synthesised from ESO through a two-step procedure. Figure 3 depicts the synthesis of a soybean oil-based polymeric surfactant. The oxirane moiety of ESO was opened in methlyene chloride or a benign media such as ethyl acetate

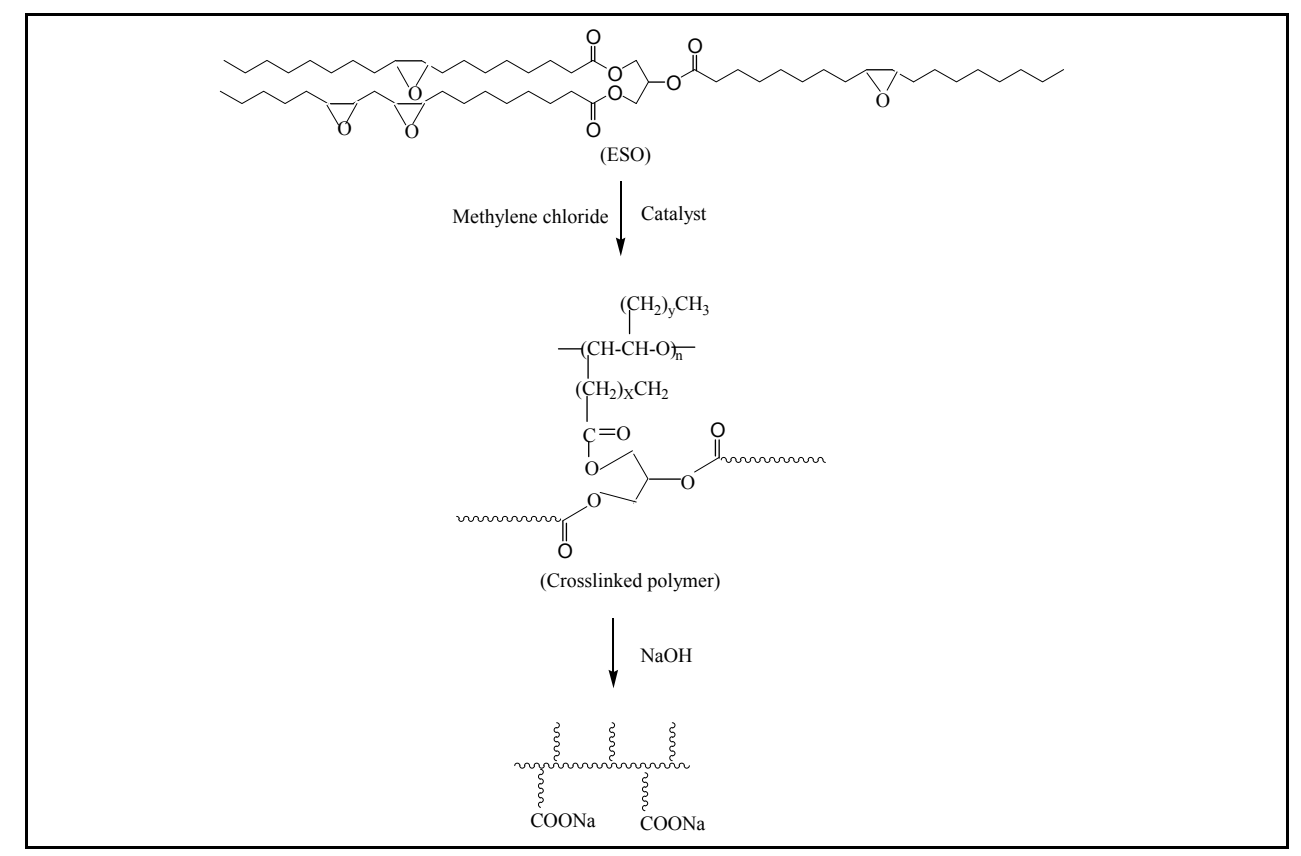

Fig. 3. The synthesis of Palozengs R-004. 
using a cationic initiator $\left(\mathrm{BF}_{3} \cdot \mathrm{OEt}_{2}\right)$. The resulting polymer was hydrolysed with a base to remove the glycerin backbone from the oil structure and obtain a polymer with free carboxylic acid groups. The resulting polyacid was then converted into polysoap by neutralising it with an appropriate base (NaOH) [Biresaw et al., 2008; Liu \& Erhan, 2010]. Recently, efforts have been paid to the preparation of ESO-derived surfactants using the environmentally-friendly solvent $\mathrm{SC}-\mathrm{CO}_{2}$, targeting applications in food, pharmaceutical delivery, and cosmetics. Polymers prepared by this method possess advantageous properties compared to that obtained by other methods.

Because the conventional methods for surfactant production are governed by several parameters, it is time-consuming to produce surfactants with desired properties through the trial and error approach. Also, some organic solvents are used. This may limit their application in food and medical areas. An attempt has been made to use computer-aided molecular design (CAMD) to address this challenge. Soybean oil-derived surfactants have been designed by taking into account important properties such as the hydrophiliclipophilic balance, the $\mathrm{CMC}$, surface tension, and wetting time. The results suggest that the structures obtained from the CAMD methodology are useful for the synthesis of surfactants with novel functionalities [Camarda \& Sunderesan, 2005].

\subsection{Properties of soybean oil-based surfactants}

Surface activity is a key parameter in the evaluation of the ability of a surfactant to reduce surface tension and to stabilise newly created surfaces. The surface activity of soybean oilbased surfactants is comparable to the reported activities of microbial surfactants [Cox et al., 2007; Lee et al., 2008] and higher than those of some of the conventional synthetic surfactants [Xu et al., 2009]. The surface tension of Milli-Q water was reduced to a minimum value of less than $30 \mathrm{mN} / \mathrm{m}$. The surface activity was found to be affected by the type of counter ion and molecular weight [Biresaw et al., 2008]. An ESO-derived surfactant, Palozengs (R-004), exhibited a unique aggregation behaviour and formed small aggregates (sub-micelles or pre-micelles) at very low concentrations. A further increase in concentration resulted in an increase in aggregate size and polydispersity. Monomers and aggregates with different sizes may coexist in surfactant systems. It is generally assumed that aggregation takes place at the CMC or critical aggregation concentration (CAC). The physico-chemical properties of a surfactant change markedly above and below the CMC. Hence, the CMC is an important parameter for evaluating surfactants and for the selection of a suitable surfactant and the optimum surfactant concentration in practical applications. Normally, a surfactant concentration higher than the CMC is needed to effectively prepare dispersed systems. The CMC can be determined by measuring the changes in physical properties such as electrical conductivity, turbidity, surface tension, and interfacial tension. Among these methods, the surface tension method is the most commonly used method. The breakpoint in the surface tension-surfactant concentration curve is generally referred to as the CMC. In the case of R-004, however, it was found that the CMC or CAC determined by the surface tension method may not accurately represent the concentration at which aggregation starts. The formation of sub-micelles has also been reported in casein [Koczo et al., 1996], SC3 hydrophobin [Corvis et al., 2006] and low molecular weight versus such as SDS [Cui et al., 2008]. In these cases, the CMC obtained from the adsorption isotherm may correspond to saturation of the interface. The inflection in the plot of surface tension versus concentration was defined as the surface saturated concentration (SSC) rather than as the CMC or CAC [Cox et al., 2007]. Zeta-potential measurements confirmed that R-004 is an anionic surfactant 
due to the presence of carboxylic groups. The absolute value of the zeta-potential greatly increased with increasing R-004 concentration, suggesting an increase in aggregation number and surface charge density [Xu et al., 2010].

\subsection{Applications of soybean oil-based surfactants}

Wong et al. [2006] used a soybean oil-based surfactant to fabricate solid lipid nanoparticles for the delivery of an anticancer drug, doxorubicin hydrochloride (Dox). The obtained nanoparticles had a size range of $80-350 \mathrm{~nm}$ with a drug encapsulation efficiency of $60-80 \%$. It was found that about $50 \%$ of the loaded drug was released in the first few hours, and an additional $10-20 \%$ was released within two weeks. An enhancement in cytotoxicity was confirmed, suggesting a potential application in drug delivery and cancer treatment. The hydrogels formed by soybean oil-based polymers exhibited viscoelastic solid or gel behaviour at concentrations above $2 \%$ (wt. \%) at room temperature. The hydrogels possess attractive properties for applications in the encapsulation of drugs, functional compounds, and cells [Xu et al., 2008a].

Along with the dispersed systems mentioned above, bubble dispersion is an important dispersed system. Bubbles are ubiquitously present in biological systems and in industrial and agricultural products. Bubbles can be divided into two types according to their morphology: well-separated spherical bubbles and interlinked polyhedral bubbles. The former are referred to as bubbles while the latter are referred to as foams [Xu et al., 2008b]. Numerous studies have been performed on the use of microubbles as ultrasound contrast agents [Wheatley et al., 2006] and as delivery systems for drugs and genes [Tsutsui et al., 2004]. The application of microbubbles has been extended to aquaculture, hydroponic cultivation, water purification, and sewage treatment [Onari, 2005; Takahashi, 2005]. Although promising results have shown the great potential of micro-/nanobubble-based technology, the lack of well-established generation and characterization methods remains a major challenge in understanding the properties of micro-/nanobubbles and their applications. Xu et al. [2008b] revealed that the properties of microbubbles depend on their generation method and the surfactant used. An important property of microbubbles that distinguishes them from the conventional large bubbles is that they shrink when their size is below a critical value. The rate of shrinkage significantly increases with a decrease in the size of microbubbles due to an increased internal pressure. Therefore, it is technically and theoretically difficult to prepare tiny bubbles and even more difficult to stabilised them [Xu et al., 2008b; 2009]. Regardless of their difficulty in preparation and stabilisation, micro/ nanobubbles are gaining more interest from both fundamental and applied points of view. The ability of the soybean oil-based surfactant R-004 to form and stabilise microbubbles was evaluated by measuring the size distribution and changes in the average bubble size over time. No obvious differences in size distribution and average bubble size were found between the concentrations below and above the SSC, suggesting the high efficiency of R004 in bubble preparation and the possibility to produce microbubbles with a lesser amount of surfactant. The bubble dispersions were separated into two distinct layers within minutes after preparation: the milky upper layer and clear lower layer. The upper layer contained larger microbubbles with diameters that increased with time. The height of the upper layer decreased with time and finally disappeared. On the other hand, the clear lower layer contained stable tiny bubbles (Fig. 4). It was proposed that the hydrophobic moiety of the R004 molecule conferred a substantial degree of hydrophobicity to R-004, allowing it to strongly adsorb at the bubble surface and form a protective adsorbed layer to stabilise the 
bubbles. Moreover, the polyelectrolytic properties of R-004 contributed to the electrostatic stabilisation of the bubbles.

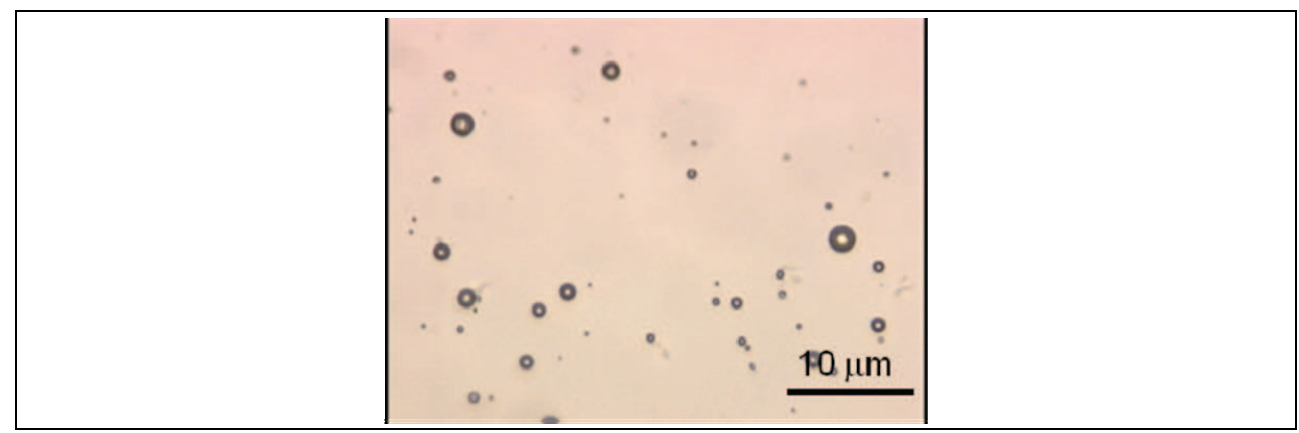

Fig. 4. Bubbles prepared with 0.1\% filtered R-004 (one day after sonication).

The obtained results have revealed that soybean oil-based surfactants possess unique and interesting properties. They have several advantages over conventional synthetic surfactants, such as high surface activities, biodegradability, biocompatibility, and costeffectiveness [Wong et al., 2006; Xu et al., 2008a]. The formation and stabilisation of microbubbles are affected by the characteristics of R-004 aggregates [ $\mathrm{Xu}$ et al., 2010], suggesting the importance of investigating the relationship between the structure and function of the surfactants. Unlike soy lecithins and soy proteins, it may be said that the production and utilisation of soybean oil-based surfactants are just at the initial phases. Because the functionalities of surfactants are dependent on their solubilities, charges, sizes, degrees of polymerisation, an understanding of the effect of the production conditions on the properties of soybean oil-based surfactants is necessary to produce surfactants with desired functionalities. Further study is required to investigate the effects of factors such as $\mathrm{pH}$ and the type and concentration of electrolytes on the surfactant aggregation as well as on the formation and stabilisation of dispersed systems. Soybean oil-based surfactants have shown a potential for their application in the food, pharmaceutical, and cosmetic industries. To improve the functionalities of soybean oil-based surfactants and the quality of products, the elucidation of the interactions between the soybean oil-based surfactants and low molecular weight surfactants, proteins, polysaccharides, and other components is thus becoming an important research priority.

\section{Conclusions}

There is a considerable amount of literature devoted to the nutritional functionality and health benefits of soybeans. In this chapter, we focus on the surfactants from soybeans, which have been widely used in various industries, including the food, cosmetic, and pharmaceutical industries. It can be expected that the demand for the production of soybean-based surfactants will continue to increase. Currently, a number of technologies are available for modifying soybean-derived surfactants to achieve improved functionalities. The major challenge for the future is to produce surfactants with tailored structures and properties. For this purpose, a better understanding of the relationship between the structure and functionality of the surfactants is necessary. Compared with soy lecithins and 
soy proteins, the production and utilisation of soybean oil-derived surfactants are still in the early stages. Recent studies on these surfactants were introduced with an emphasis on the preparation of microbubbles. Although a great potential for the application of soybean oilderived surfactants has been shown, further investigation into the characterisation of their properties is required to fully exploit their functionalities. In addition, it is scientifically and practically important to elucidate the mechanisms of formation and stabilisation in various dispersed systems. The combination of soybean oil-derived surfactants and low molecular weight surfactants, proteins, or polymers will be a challenge in extending their applications to new fields.

\section{Acknowledgment}

This research was financially supported by the Food Nanotechnology Project of the Ministry of Agriculture, Forestry and Fisheries of Japan.

\section{References}

Acmite market intelligence (2008), World surfactant market: markets,products, applications, innovations, chances $\mathcal{E}$ risks, competition, prospects to 2015. Ratingen.

Angelico, R.; Ceglie, A.; Colafemmina, G.; Delfine, F.; Olsson, U. \& Palazzo, G. (2004). Phase Behavior of the Lecithin/Water/Isooctane and Lecithin/Water/Decane Systems, Langmuir, Vol. 20, No. 2, 619-631, ISSN: 0743-7463.

American Soybean Association (2010). http:/ / soystats.com/2010/ Default-frames.htm.

BIBRA (The British Industrial Biological Research Association) (1988). Toxicity profile: epoxidised soy bean oil, Carlshalton.

Biresaw, G.; Liu, Z. \& Erhan, S.Z. (2008). Investigation of the surface properties of polymeric soaps obtained by ring-opening polymerization of epoxidized soybean oil. J. Appl. Polym. Sci., Vol. 108, No. 3, 1976-1985, ISSN: 0021-8995.

Boode, K.; Bisperink, C. \& Walstra, P. (1991). Destabilization of O/W emulsions containing fat crystals by temperature cycling, Colloids and Surfaces, Vol. 61, December, 55-74.

Camarda, K. V. \& Sunderesan, P. (2005). An Optimization Approach to the Design of ValueAdded Soybean Oil Products, Ind. Eng. Chem. Res., Vol. 44, No. 12, 4361-4367, ISSN: 0888-5885.

Castelain, C.; Renard, D.; Bronnec, I. \& Laroche, M. (1990). Stability of lecithin-stabilized emulsions in the presence of sucrose or hydroxyethylcellulose, Food Hydrocolloids, Vol. 4, No. 3, 205-214, ISSN: 0268-005X.

Chove, B. E.; Grandison, A. S. \& Lewis, M. J. (2007). Some functional properties of fractionated soy protein isolates obtained by microfiltration, Food Hydrocolloids, Vol. 21, No. 8, 1379-1388, ISSN: 0268-005X.

Cirelli, A. F.; Ojeda, C.; Castro, M. J. L. \& Salgot, M. (2008). Surfactants in sludge-amended agricultural soils, Environ. Chem. Lett. Vol. 6, No. 3, 135-148, ISSN: 1610-3653.

Comas, D. I.; Wagner, J. R. \& Tomás, M. C. (2006). Creaming stability of oil in water (O/W) emulsions: Influence of $\mathrm{pH}$ on soybean protein-lecithin interaction, Food Hydrocolloids, Vol. 20, No. 7, 990-996, ISSN: 0268-005X.

Corvis, Y.; Brezesinski, G.; Rink, R.; Walcarius, A.; Heyden, A. V. D.; Mutelet, F. \& Rogalska, E. (2006). Analytical Investigation of the Interactions between SC3 Hydrophobin 
and Lipid Layers: Elaborating of Nanostructured Matrixes for Immobilizing Redox Systems, Anal. Chem., Vol. 78, No. 14, 4850-4864, ISSN: 0003-2700.

Cox, A. R.; Cagnol, F.; Russell, A. B. \& Izzard, M. J. (2007). Surface Properties of Class II Hydrophobins from Trichoderma reesei and Influence on Bubble Stability, Langmuir, Vol. 23, No. 15, 7995-8002, ISSN: 0743-7463.

Cruijsen, J. M. M. (1996). Physical stability of caseinate - stabilized emulsions during heating, Ph.D. Thesis, Agricultural University, Wageningen, The Netherlands.

Cui, X.; Mao, S.; Liu, M.; Yuan, H. \& Du, Y. (2008). Mechanism of Surfactant Micelle Formation, Langmuir, Vol. 24, No. 19,10771-10775, ISSN: 0743-7463.

Damodaran, S. (2005). Protein Stabilization of Emulsions and Foams, J. Food Sci., Vol. 70, No. 3, R54-66, ISSN: 0022-1147.

Dashiell, G. L. \& Prosise, W. E. (1984). Method of preparing heat resistant lecithin release agent, United States Patent 4479977.

Dickinson, E. \& Galazka, V. B. (1991). Emulsion stabilization by ionic andcovalent complexes of $\beta$-lactoglobulin with polysaccharides, Food Hydrocolloids, Vol. 5, No. 3, 281-296, ISSN: 0268-005X.

Dickinson, E. (1993). Towards more natural emulsifiers, Trends Food Sci. Tech., Vol. 4, No. 10, 330-334, ISSN: 0924-2244.

Dickinson, E. \& Tanai, S. (1992). Protein Displacement from the Emulsion Droplet Surface by Oil-Soluble and Water-Soluble Surfactants, J. Agr. Food Chem., Vol. 40, No. 2, 179183, ISSN: 0021-8561.

Dickinson, E. \& Yamamoto, Y. (1996). Viscoelastic Properties of Heat-Set Whey ProteinStabilized Emulsion Gels with Added Lecithin, J. Food Sci., Vol. 61, No. 4, 811-816, ISSN: 0022-1147.

Dickinson, E. (1997). Properties of Emulsions Stabilized with Milk Proteins: Overview of Some Recent Developments, J. Dairy Sci., Vol. 80, No. 10, 2607-2619, ISSN: 00220302.

Dickinson, E. (2003). Hydrocolloids at interfaces and the influence on the properties of dispersed systems, Food hydrocolloids, Vol. 17, No. 1, 25-39, ISSN: 0268-005X.

Diftis, N., \& Kiosseoglou, V. (2004). Competitive adsorption between a dry heated soy protein dextran mixture and surface active materials in oil-in-water emulsions. Food Hydrocoloids, Vol. 18, No. 6, 639-646, ISSN: 0268-005X.

Dornbos, D. L.; Mullen, R. E. \& Hammond, E. G. (1989). Phospholipids of Environmentally Stressed Soybean Seeds, JAOCS, Vol. 66, No. 9, 1371-1373, ISSN: 0003-021X.

EFSA (2004). Opinion of the scientific panel on food additives, flavourings, processing aids and materials in contact with food (AFC) on a request from the commission related to the use of epoxidised soybean oil in food contact materials. EFSA Journal, Vol. 64, $1-17$.

Endres, J. G. (2001). Soy protein products: characteristics, nutritional aspects, and utilization, Revised and expanded edition, AOCS Press, ISBN 1-893997-27-8, Champaign.

Farook, U.; Stride, E. \& Edirisinghe, M. J. (2009). Preparation of suspensions of phospholipid-coated microbubbles by coaxial electrohydrodynamic atomization, J. R. Soc. Interface, Vol. 6, No. 32, 271-277 、ISSN: 1742-5689.

Foegeding, E.; Luck, P. \& Davis, J. (2006). Factors determining the physical properties of protein foams. Food Hydrocolloids, Vol. 20, No.2-3, 284-292, ISSN: 0268-005X. 
Garti, N. (2002). Food emulsifiers: structure-reactivity relationships, design, and applications, In: Physical properties of lipids, Marangoni, A. G. \& Narine, S. (Ed.), 265386, Marcel Dekker, Inc., ISBN: 978-0-8247-0005-8, New York.

Gierula, M. P.; Takaoka, Y.; Miyagawa, H.; Kitamura, K. \& Kusumi, A. (1999). Charge Pairing of Headgroups in Phosphatidylcholine Membranes: A Molecular Dynamics Simulation Study, Biophys. J., Vol. 76, No. 3, 1228-1240, ISSN: 0006-3495.

Guo, Y.; Hardesty, J. H.; Mannari, V. M. \& Massingill, J. L. (2007). Hydrolysis of Epoxidized Soybean Oil in the Presence of Phosphoric Acid, JAOCS, Vol. 84, No. 10, 929-935, ISSN: 0003-021X.

Hamada, J. S. \& Marshall, W. E. (1989). Preparation and functional properties of enzymatically deamidated soy proteins, J. Food Sci., Vol. 54, No. 3, 598-601, ISSN: 0022-1147.

Hamada, J. S. (1992). Effects of heat and proteolysis on deamidation of food proteins using peptidoglutaminase, J. Agr. Food Chem., Vol. 40, No.5, 719-723, ISSN: 0021-8561.

Hirotsuka, M.; Taniguchi, H.; Narita, H. \& Kito, M. (1984). Increase in emulsification activity of soy lecithin-soy protein complex by ethanol and heat treatments. J. Food Sci., Vol. 49, No. 4, 1105-1110, ISSN: 0022-1147.

Iwabuchi, S. \& Yamauchi F. (1987). Determination of glycinin and .beta.-conglycinin in soybean proteins by immunological methods, J. Agr. Food Chem., Vol. 35, No. 2, 200-205, ISSN: 0021-8561.

Johansson, D. \& Bergenståhl, B. (1992). The Influence of Food Emulsifiers on Fat and Sugar Dispersions in Oils. I. Adsorption, Sedimentation, JAOCS, Vol. 69, No. 8, 705-717, ISSN: 0003-021X.

Jambrak, A. R.; Lelas, V.; Mason, T. J.; Krešić, G. \& Badanjak, M. (2009). Physical properties of ultrasound treated soy proteins, J. Food Eng., Vol. 93, No. 4, 386-393, ISSN: 02608774.

Joshi, A.; Paratkar, S. G. \& Thorat, B. N. (2006). Modification of lecithin by physical, chemical and enzymatic methods, Eur. J. Lipid Sci. Tech., Vol. 108, No. 4, 363- 373, ISSN: 14387697.

Kajiyama, N.; Isobe, S.; Uemura, K. \& Noguchi, A. (1995). Changes of soy protein under ultra-high hydraulic pressure, Int. J. Food Sci. Tech, Vol. 30, No. 2, 147-158, ISSN: 0950-5423.

Karsa, D. R. \& Houston, J. (2006). Chapter 1: What are surfactants, In: Chemistry and technology of surfactants, Farn r. J. (Ed.), 1-23, Blackwell Publishing Ltd., ISBN: 97814051-2696-0, Oxford.

Kawakatsu, T.; Kikuchi, Y. \& Nakajima, M. (1997). Regular-Sized Cell Creation in Microchannel Emulsification by Visual Microprocessing Method. JAOCS, Vol. 74, No. 3, 317-321, ISSN: 0003-021X.

Kinsella, J. E. (1976). Functional properties of proteins in foods: A survey, Crit. Rev. Food Sci., Vol. 7, No. 3, 219-280, ISSN: 1040-8398.

Kolar, C. W.; Cho, I. C. \& Watrous, W. L. (1979). Vegetable protein application in yogurt, coffee creamers and whip toppings, JAOCS, Vol. 56, No. 3, 389-391, ISSN: 0003021X.

Koczo, K.; Nikolov, A. D.; Wasan, D. T.; Borwankar, R. P. \& Gonsalvest, A. (1996). Layering of sodium caseinate submicelles in thin liquid films - a new stability mechanism for food dispersions, J. Colloid Interf. Sci., Vol. 178, No. 2, 694-702, ISSN: 0021-9797. 
Krawczyk, T. (1996). "Lecithin: consider the possibilities," Int. News Fats, Oils Rel. Mat. (INFORM), Vol. 7, No.11, 1158- 1165.

Roesch, R. R. \& Corredig, M. (2003). Texture and microstructure of emulsions prepared with soy protein concentrate by highpressure homogenization. Lebensmittel Wissenschaft und Technologie, Vol. 36, No.1, 113-124, ISSN 0023-6438.

Lai, H. M. \& Lin, T. C. (2006). Bakery products: science and technology, In: Bakery products: science and technology, Hui, Y. H. (Ed.), 3-65, Blackwell Publishing, ISBN: 978-0-81380187-2,Oxford.

Lantz, R. A. (1989). Industrial methods of analysis, In: Lecithins: Sources, Manufacture and Uses, Szuhaj, B. F. (Ed.), 162-173, AOCS, ISBN: 0-935315-27-6, Champaign.

Lee, K. W.; Cheng, H.; Jin, Y.; Kim, Y. W. \& Chung, K. W. (2008). Modification of soybean oil for intermediates by epoxidation, alcoholysis and amidation, Korean J. Chem. Eng., Vol. 25, No. 3, 474-482, ISSN: 0256-1115.

Li, R. (2006). Soy product off-flavor generating, masking, and flavor creating, In: Soy applications in food, Riaz, M. N. (Ed.), 227-248, Taylor \& Francis, ISBN: 978-0-84932981-4, Boca Raton.

List, G. R. (1989). Commercial manufacture of lecithin, In: Lecithins: Sources, Manufacture and Uses, Szuhaj, B. F. (Ed.), 145-161, AOCS, ISBN: 0-935315-27-6, Champaign.

Liu, K. S. (1997). Soybeans: Chemistry, technology and utilization, ISBN: 978-0-8342-1299-2, Chapman \& Hall, New York.

Liu, Z. S. \& Erhan, S. Z. (2010). Soy-based thermosensitive hydrogels for controlled release systems, United States Patent 7691946.

Manjula, S. \& Subramanian, R. (2008), Laboratory Studies on Membrane Deoiling of Lecithin, JAOCS, Vol. 85, No. 6, 573-580, ISSN: 0003-021X.

Marellapudi, S. L. K.; Vemulapalli, V.; Penumarthy, V. \& Rachapudi, B. N. P. (2002). Enzymatic process for the preparation of an acetylated phospholipid, United States Patent 6403344.

McCrae, C. H. (1999). Heat stability of milk emulsions: phospholipid-protein interactions, J. Dairy Res., Vol. 9, No. 3-6, 227- 231, ISSN: 0022-0299.

McClements, D. J. (2005). Food emulsions: principles, practices, and techniques, CRC Press, ISBN: 978-0-8493-2023-1, Boca Raton.

McEvily, A. J. \& Zaks, A. (1991). Emulsifiers and Surfactants, In: Biotechnology and Food Ingredients, Goldberg, I. \& Williams, R. (Ed.), 193-222, Van Nostrand Reinhold, ISBN: 0442-00272-6, New York.

McSweeney, S. L. (2008). Emulsifiers in infant nutritional products, In: Food emulsifiers and their applications, Hasenhuettl, G. L. \& Hartel, R. W. (Ed.), second edition, 233-262, Springer, ISBN: 978-0-387-75283-9, New York.

Melsen, J. P. \& Walstra, P. (1989). Stability of recombined milk fat globules, Neth. Milk Dairy J. Vol. 43, No. 1, 63-78, ISSN: 0028-209X.

Miura, S.; Mutoh, T.; Shiinoki, Y. \& Yoshioka, T. (2006). Emulsifying properties of phospholipids in the reconstitution of cream using butter oil, Eur. J. Lipid Sci. Tech., Vol. 108, No. 11, 898-903, ISSN: 1438-7697.

Molina, E.; Papadopoulou, A. \& Ledward, D. A. (2001). Emulsifying properties of high pressure treated soy protein isolate and 7S and 11S globulins, Food Hydrocolloids, Vol. 15, No. 3, 263-269, ISSN: 0268-005X. 
Montanari, L.; Fantozzi, P.; Snyder, J. M. \& King, J. W. (1999). Selective Extraction of Phospholipids from Soybeans with Supercritical Carbon Dioxide and Ethanol, $J$. Supercrit. Fluid, Vol. 14, No. 2, 87-93, ISSN: 0896-8446.

Moure, A.; Sineiro, J.; Domínguez, H. \& Parajó, J. C. (2006). Functionality of oilseed protein products: A review, Food Res. Int., Vol. 39, No. 9, 945-963, ISSN: 0963-9969.

Mujoo, R.; Trinh, D. T. \& Ng, P. K. W. (2003). Characterization of storage proteins in different soybean varieties and their relationship to tofu yield and texture, Food Chemistry, Vol. 82, No. 2, 265-273.

Murry, R. S. (2007). Stabilization of bubbles and foams, Curr. Opin. Colloid In., Vol. 12, No. 45, 232-241, ISSN: 1359-0294.

Muthusamy, K.; Gopalakrishnan, S.; Ravi, T. K. \& Sivachidambaram, P. (2008). Biosurfactants: Properties, commercial production and application, Curr. Sci., Vol. 94, No. 6, 736-747, ISSN: 0011-3891.

Nakashima, T.; Shimizu, M. \& Kukizaki, M. (1991). Membrane Emulsification by Microporous Glass. Key Eng. Mater., Vol. 61-62, 513-516, ISSN: 1013-9826.

Nasir, M. I.; Bernards, M. A. \& Charpentier, P. (2007). Acetylation of Soybean Lecithin and Identification of Components for Solubility in Supercritical Carbon Dioxide, J. Agr. Food Chem., Vol. 55, No. 5, 1961-1969, ISSN: 0021-8561.

Nieuwenhuyzen, W. V. (1976). Lecithin production and properties, JAOCS, Vol. 53, No. 4, 425-427, ISSN: 0003-021X.

Nieuwenhuyzen, W. V. (1981). The Industrial Uses of Special: A Review, JAOCS, Vol. 58, No. 10, 886-888, ISSN: 0003-021X.

Nieuwenhuyzen, W. V. \& Szuhaj, B. F. (1998). Effects of lecithins and proteins on the stability of emulsions. Fett/Lipid., Vol. 100, No. 7, 282-291, ISSN: 1521-4133.

Nieuwenhuyzen, W. V. \& Tomas, M. C. (2008). Update on vegetable lecithin and phospholipid technologies, Eur. J. Lipid Sci. Tech., Vol. 110, No. 5, 472-486, ISSN: 1438-7697.

Nieuwenhuyzen, W. V. (2010). Lecithin and other phospholipids, In: Surfactants from renewable resources, Wiley Series in Renewable Resources, Kjellin, M., Johansson, I. (Ed.), 191-212, Wiley, ISBN: 978-0-470-76041-3, West Sussex.

Ogawa, S.; Decker, E. A. \& McClements, D. J. (2003). Influence of Environmental Conditions on the Stability of Oil in Water Emulsions Containing Droplets Stabilized by Lecithin-Chitosan Membranes, J. Agr. Food Chem., Vol. 51, No. 18, 5522-5527, ISSN: 0021-8561.

Ogden, L. G. \& Rosenthal, A. J. (1997). Interactions between tristearin crystals and proteins at the oil-water interface. J. Colloid Interf. Sci., Vol. 191, No. 1, 38-47, ISSN: 00219797.

Oleszek, W. \& Hamed, A. (2010). Saponin-based surfactants, In Surfactants from renewable resources, Wiley Series in Renewable Resources, Kjellin, M. \& Johansson, I. (Ed.), 239252, Wiley, ISBN: 978-0-470-76041-3, West Sussex.

Onari, H. (2005). Microbubbles and its application to the fisheries technology. In: Concepts in Basic Bubble and Foam Engineering, Ishii, T.; Tamura, T.; Tsukada, T. \& Tsujii, K. (Ed.), 475-484, Techno System, ISBN: 978-4924728479, Tokyo.

Ortiz, S. E. M. \& Wagner, J. R. (2002). Hydrolysates of native and modified soy protein isolates: structural characteristics, solubility and foaming properties, Food Res. Int., Vol. 35, No. 6, 511-518, ISSN: 0963-9969. 
Park, S. K.; Hettiarachchy, N. S.; Ju, Z. Y. \& Gennadios, A. (2002). Formation and properties of soy protein films and coatings, In: Protein-based films and coatings, Gennadios, A. (Ed.), pp123-138, CRC Press, ISBN: 978-1587-16107-0, Boca Raton.

Patel, M. (2003). Surfactants based on renewable raw materials: carbon dioxide reduction potential and policies and measures for the European Union, J. Ind. Ecol. Vol. 7, No. 3-4, 47-62, ISSN: 1088-1980.

Pedersen, K. B. (2001). Interesterfication of phospholipids. United States Patent 6284501.

Palazzo, G.; Angelico, R.; Ceglie, A. \& Olsson, U. (2003). Lecithin organogels: structure, dynamics and phase behavior, In: Self-assembly, Robinson, B. H. (Ed.), 318-328, IOS Press, ISBN: 1-58603-382-4, Burke.

Puppo, M.C.; Speroni, F.; Chapleau, N.; Lamballerie, M.; Añón, M. C. \& Anton, M. (2005). Effect of high-pressure treatment on emulsifying properties of soybean proteins, Food Hydrocolloids, Vol. 19, No. 2, 289-296, ISSN: 0268-005X.

Roudsari, M.; Nakamura, A.; Smith, A. \& Corredig, M. (2006). Stabilizing Behavior of Soy Soluble Polysaccharide or High Methoxyl Pectin in Soy Protein Isolate Emulsions at Low pH, J. Agr. Food Chem., Vol. 54, No. 4, 1434-1441, ISSN: 0021-8561.

Rousseau, D. (2000). Fat crystals and emulsion stability: a review, Food Res. Int., Vol. 33. No. 1, 3-14, ISSN: 0963-9969.

Rust D. \& Wildes, S. (2008). Surfactants: a market opportunity study update, United soybean board, Omni Tech International, Ltd., Midland.

Rydhag, L. \& Wilton, I. (1981). The function of phospholipids of soybean lecithin in emulsions, JAOCS, Vol. 58, No. 8, 830-837, ISSN: 0003-021X.

Schneider, M. (1989). Fractionation and Purification of Phospholipids, In: Lecithins: Sources, Manufacture, and Uses, Szuhaj, B. F. (Ed.), 109-130, American Oil Chemists' Society, ISBN: 0-935315-27-6, Champaign.

Scuriatti, M. P.; Tomás, M. C. \& Wagner, J. R. (2003). Influence of Soybean Protein IsolatesPhosphatidycholine Interaction on the Stability of Oil-in-Water Emulsions, JAOCS, Vol. 80, No. 11, 1093-1100, ISSN: 0003-021X.

Stefan, A.; Palazzo, G.; Ceglie, A.; Panzavolta, E. \& Hochkoeppler, A. (2003). Water-in-oil macroemulsions sustain long-term viability of microbial cells in organic solvents, Biotechnol Bioeng., Vol. 81, No. 3, 323-328, ISSN: 0006-3592.

Surh, J.; Jeong, Y. G. \& Vladisavljević, G. T. (2008). On the preparation of lecithin-stabilized oil-in-water emulsions by multi-stage premix membrane emulsification, J. Food Eng., Vol. 89, No. 2, 164-170, ISSN: 0260-8774.

Takahashi, S. (2005). Engineering applications of microbubbles. In: Concepts in Basic Bubble and Foam Engineering, Ishii, T.; Tamura, T.; Tsukada, T. \& Tsujii, K. (Ed.), 463-474, Techno System, ISBN: 978-4924728479, Tokyo.

Teberikler, L.; Koseoglu, S. \& Akgerman, A. (2001). Selective Extraction of Phosphatidylcholine from Lecithin by Supercritical Carbon Dioxide/Ethanol Mixture, JAOCS, Vol. 78, No. 2, 115-120, ISSN: 0003-021X.

Taylor, T. M.; Davidson, P. M.; Bruce, B. D. \& Weiss, J. (2005). Liposomal Nanocapsules in Food Science and Agriculture, Crit. Rev. Food Sci., Vol. 45, No. 7-8, 587-605, ISSN: 1040-8398.

Tong, J.; Nakajima, M. \& Nabetani, H. (2002). Preparation of phospholipid oil-in-water microspheres by microchannel emulsification technique, Eur. J. Lipid Sci. Tech. Vol. 104, No. 4, 216-221, ISSN: 1438-7697. 
Tsutsui, J. M.; Xie, F. \& Porter, R. T. (2004). The use of microbubbles to target drug delivery, Cardiovasc. Ultrasound, 2:23, ISSN: 1476-7120.

Vani, B. \& Zayas, J. F. (1995). Foaming properties of selected plant and animal proteins. J. Food Sci., Vol. 60, No. 5, 1025-1028, ISSN: 0022-1147.

Vikbjerg, A. F.; Rusig, J. Y.; Jonsson, G.; Mu, H. \& Xu, X. (2006). Comparative Evaluation of the Emulsifying Properties of Phosphatidylcholine after Enzymatic Acyl Modification, J. Agr. Food Chem., Vol. 54, No. 9, 3310-3316, ISSN: 0021-8561.

Vladisavljević, G. T.; Shimizu, M. \& Nakashima, T. (2005). Permeability of hydrophilic and hydrophobic Shirasus-porous glass (SPG) membranes to pure liquids and its microstructure, J. Membrane Sci., Vol. 250, No. 1-2, 69-77, ISSN: 0376-7388.

Wang, G. \& Wang, T. (2008). Oxidative stability of egg and soy lecithin as affected by transition metal ions and $\mathrm{pH}$ in emulsion, J. Agric. Food Chem., Vol. 56, No. 23, 11424-11431, ISSN: 0021-8561.

Wheatley, M.; Forsberg, F.; Dube, N.; Patel, M. \& Oeffinger B. (2006). Surfactant-stabilized contrast agent on the nanoscale for diagnostic ultrasound imaging, Ultrasound Med. Biol., Vol. 32, No. 1, 83-93, ISSN: 0301-5629.

Weyland, M. \& Hartel, R. (2008). Emulsifiers In: Confectionery, in Food emulsifiers and their applications, Hasenhuettl, G. L. \& Hartel, R. W. (Ed.), second edition, 285-306, Springer, ISBN: 978-0-387-75283-9, New York.

WHO. (1974). Toxicological evaluation of some food additives including anticaking agents, antimicrobials, antioxidants, emulsifiers and thickening agents, in WHO Food Additives Series (FAS), NO. 5, Geneva.

Wong, H. L.; Rauth, A. M.; Bendayan, R.; Manias, J. L.; Ramaswamy, M.; Liu, Z.; Erhan, S. Z. \& Wu, X. Y. (2006). A new polymer-lipid hybrid nanoparticle system increases cytotoxicity of doxorubicin against multidrug-resistant human breast cancer cells. Pharm. Res-Dordr., Vol. 23, No. 7, 1574-1585, ISSN: 0724-8741.

Wu, Y. \& Wang, T. (2003). Soybean Lecithin Fractionation and Functionality, JAOCS, Vol. 80, No. 4, 319-326, ISSN: 0003-021X.

Wu, Y. \& Wang, T. (2004). Fractionation of Crude Soybean Lecithin with Aqueous Ethanol, JAOCS, Vol. 81, No. 7, 697-704, ISSN: 0003-021X.

$\mathrm{Xu}$, J.; Liu, Z. \& Erhan, S. Z. (2008a). Viscoelastic Properties of a Biological Hydrogel Produced from Soybean Oil, JAOCS, Vol. 85, No. 3, 285-290, ISSN: 0003-021X.

Xu, Q. Y.; Nakajima, M.; Ichikawa, S.; Nakamura, N. \& Shiina, T. (2008b). A comparative study of microbubble generation by mechanical agitation and sonication, Innov. Food Sci. Emerg., Vol. 9, No. 4, 489-494, ISSN: 1466-8564.

Xu, Q. Y.; Nakajima, M.; Ichikawa, S.; Nakamura, N.; Roy, P.; Okadome H. \& Shiina, T. (2009). Effects of surfactant and electrolyte concentrations on bubble formation and stabilization, J. Colloid Interf. Sci., Vol. 332, No. 1, 208-214, ISSN: 0021-9797.

Xu, Q. Y.; Liu, Z. S.; Nakajima, M.; Ichikawa, S.; Nakamura, N.; Roy, P.; Okadome H. \& Shiina, T. (2010). Characterization of a soybean oil-based biosurfactant and evaluation of its ability to form microbubbles, Bioresource Technol., Vol. 101, No.10, 3711-3717, ISSN: 0960-8524. 


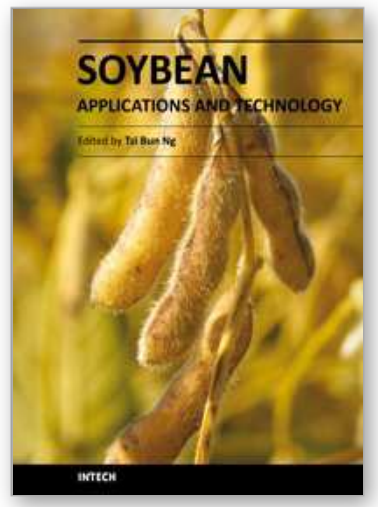

\section{Soybean - Applications and Technology \\ Edited by Prof. Tzi-Bun Ng}

ISBN 978-953-307-207-4

Hard cover, 402 pages

Publisher InTech

Published online 26, April, 2011

Published in print edition April, 2011

Soybean is an agricultural crop of tremendous economic importance. Soybean and food items derived from it form dietary components of numerous people, especially those living in the Orient. The health benefits of soybean have attracted the attention of nutritionists as well as common people.

\section{How to reference}

In order to correctly reference this scholarly work, feel free to copy and paste the following:

Qingyi Xu, Mitsutoshi Nakajima, Zengshe Liu and Takeo Shiina (2011). Soybean-based Surfactants and Their Applications, Soybean - Applications and Technology, Prof. Tzi-Bun Ng (Ed.), ISBN: 978-953-307-207-4, InTech, Available from: http://www.intechopen.com/books/soybean-applications-and-technology/soybeanbased-surfactants-and-their-applications

\section{INTECH}

open science | open minds

\section{InTech Europe}

University Campus STeP Ri

Slavka Krautzeka 83/A

51000 Rijeka, Croatia

Phone: +385 (51) 770447

Fax: +385 (51) 686166

www.intechopen.com

\section{InTech China}

Unit 405, Office Block, Hotel Equatorial Shanghai

No.65, Yan An Road (West), Shanghai, 200040, China

中国上海市延安西路65号上海国际贵都大饭店办公楼405单元

Phone: +86-21-62489820

Fax: $+86-21-62489821$ 
(C) 2011 The Author(s). Licensee IntechOpen. This chapter is distributed under the terms of the Creative Commons Attribution-NonCommercialShareAlike-3.0 License, which permits use, distribution and reproduction for non-commercial purposes, provided the original is properly cited and derivative works building on this content are distributed under the same license. 